\title{
Profile of 17ß-estradiol, vitellogenin, and egg diameter during gonad maturation process of striped catfish Pangasianodon hypophthalmus
}

\author{
Profil 17ß-estradiol, vitelogenin dan diameter telur pada proses \\ pematangan gonad ikan patin siam Pangasianodon hypophthalmus
}

\author{
Wahyu Pamungkas ${ }^{1,2}$, Dedi Jusadi', Muhammad Zairin Jr., Mia Setiawati", \\ Eddy Supriyono', Imron ${ }^{2}$

\begin{abstract}
'Department of Aquaculture, Faculty of Fisheries and Marine Sciences, IPB University (Bogor Agricultural University), Bogor 16680, West Java, Indonesia

${ }^{2}$ Research Institute for Fish Breeding, Subang 41256, West Java, Indonesia.

*Corresponding author: siflounder@gmail.com
\end{abstract}

(Received December 4, 2018; Accepted May 3, 2019)

\begin{abstract}
This study was conducted to evaluate the profile of 17ß-estradiol (E2) and vitellogenin (Vtg) in plasma and egg diameter during gonad maturity process of striped catfish Pangasianodon hypophthalmus. Blood samples were collected from immature striped catfish, male and female with different stage of gonad maturity (stage I, II, III, and IV) to measure the concentrations of E2 and Vtg. Gonad maturity development of striped catfish was observed based on egg diameter. Result showed that E2 concentrations were the highest $(843.65 \mathrm{pg} / \mathrm{mL})$ on female with maturity stage III, the lowest on the male $(26.34 \mathrm{pg} / \mathrm{mL})$, and immature female fish $(29.37 \mathrm{pg} / \mathrm{mL})$. The protein band of Vtg was obtained on the plasma of the mature female (stage I, II, III, and IV) with a molecular weight (MW) between 140-180 kDa, but it was not obtained on immature female dan male striped catfish. The highest concentration of Vtg was found in the plasma of the female fish with maturity stage III $(87.34 \mathrm{mg} / \mathrm{mL})$, then on the stage II $(74.83 \mathrm{mg} / \mathrm{mL})$, I $(68.58 \mathrm{mg} / \mathrm{mL})$, and IV $(33.45 \mathrm{mg} / \mathrm{mL})$. It showed that egg yolk formation occurred in the female mature. The average egg diameter was $0.107 \pm 0.052 \mathrm{~mm}, 0.318 \pm 0.086 \mathrm{~mm}, 0.864 \pm 0.099 \mathrm{~mm}$, and $1.041 \pm 0.058 \mathrm{~mm}$ on the maturity stage I, II, III, and IV respectively. The increase of egg diameter along with development of gonad maturity stage indicated that egg development occurred due to the process of vitellogenesis and the addition of egg yolk on oocyte.
\end{abstract}

Keywords : egg diameter, gonad maturity, striped catfish, 17ß-estradiol, vitellogenin

\begin{abstract}
ABSTRAK
Penelitian dilakukan untuk mengevaluasi profil 17ß-estradiol (E2), vitelogenin (Vtg) dalam plasma dan diameter telur pada proses pematangan gonad ikan patin siam Pangasianodon hypophthalmus. Sampel darah untuk pengukuran konsentrasi E2 dan Vtg plasma diperoleh dari ikan patin siam betina yang belum matang gonad, ikan jantan, ikan betina dengan tahap kematangan gonad yang berbeda (tahap I, II, III, dan IV). Perkembangan kematangan gonad ikan patin siam diamati berdasarkan diameter telur. Hasil penelitian menunjukkan bahwa konsentrasi E2 tertinggi $(843,65 \mathrm{pg} / \mathrm{mL})$ pada ikan betina dengan kematangan tahap III, terendah pada ikan jantan $(26,34 \mathrm{pg} / \mathrm{mL})$, dan ikan betina tidak matang gonad $(29,37 \mathrm{pg} / \mathrm{mL})$. Pita protein Vtg pada sampel plasma diperoleh dari betina matang gonad (tahap I, II, III, dan IV) dengan berat molekul antara 140-180 kDa, tetapi tidak diperoleh pada ikan patin siam betina yang belum dewasa dan jantan. Nilai konsentrasi tertinggi Vtg ditemukan dalam plasma darah ikan betina dengan tingkat kematangan III $(87,34 \mathrm{mg} / \mathrm{mL})$ kemudian pada tahap II $(74,83 \mathrm{mg} / \mathrm{mL})$, I $(68,58 \mathrm{mg} / \mathrm{mL})$ dan IV $(33,45 \mathrm{mg} / \mathrm{mL})$. Hal ini menunjukkan bahwa pada ikan betina dewasa terjadi proses pembentukan kuning telur (vitelogenesis). Rata-rata diameter telur adalah 0,107 $\pm 0,052 \mathrm{~mm}, 0,318 \pm 0,086 \mathrm{~mm}$, $0,864 \pm 0,099 \mathrm{~mm}$ dan $1,041 \pm 0,058 \mathrm{~mm}$ pada tingkat kematangan I, II, III, dan IV secara berurutan. Peningkatan nilai diameter telur seiring dengan perkembangan tahap kematangan gonad menunjukkan bahwa perkembangan telur terjadi karena proses vitelogenesis dan penambahan bahan kuning telur pada oosit.
\end{abstract}

Kata kunci : diameter telur, 17ß-estradiol, kematangan gonad, patin siam, vitelogenin 


\section{INTRODUCTION}

The striped catfish Pangasianodon hypophthalmus is a superior freshwater species in South East Asia, especially in Vietnam (Phan et al., 2009; Bui et al., 2010), Malaysia (Asdari et al., 2010), India (Singh \& Lakra, 2012; Kumar et al., 2013), and Bangladesh (Ahmed et al., 2013). This species is also recognized as a superior aquaculture species in tropical regions, as well as a major aquaculture product on world markets (McGee, 2014). Striped catfish Pangasianodon hypophthalmus, which is a high economic value commodity, has been widely produced in Indonesia for many years. According to the Ministry of Fisheries and Marine Affairs Republic of Indonesia (2018), the market price ranges between $\mathrm{Rp} 20,000$ and $\mathrm{Rp} 27,000$ per $\mathrm{kg}$ for consumption size. The striped catfish fillet industry continues to grow as the demand increases on both local and global markets. However, striped catfish culture faces several crucial problems, such as the continuity of seed availability, also the quality and quantity of mature broodstock resulted in unsustainable seed production. It potentially happens because naturally, striped catfish spawns in a certain seasons. The main spawning season of catfish commonly occurs in the rainy season, whereas in the dry season it is demanding to find the mature female (Moses et al., 2016). Scientific information about the reproductive physiology is limited. Scientific research about striped catfish reproduction is required to improve production. In the recent years, the reproductive biology of many fish species have been studied by analyzing the vitellogenin (Vtg) and 17ß-estradiol (E2) levels in the blood plasma (Muhammad et al., 2011; Tirado et al., 2017; Luck et al., 2019). Variations in steroids have been shown to be correlated with the reproductive cycle (Liu et al., 2008; Yan et al., 2011; Ni et al., 2013).

The vitellogenin, as an egg yolk protein precursor, is generated in the liver under the control of estrogen hormone and transported to ovary through the bloodstream (Reading et al., 2017). Furthermore, it is absorbed by vitellogenin receptors (VtgRs) on the surface of growing oocytes (Dominguez et al., 2012). In several species, Vtg has a molecular weight (MW) between 140-200 kDa (Komatsu \& Hayashi, 1997). Ding (2005) reported that Vtg has a MW between 200-700 kDa, similar to killifish, Fundulus heteroclitus $(200 \mathrm{kDa})$. In mature female of teleost oviparous species, the Vtg is an essential nutrition source for oocyte and embryo development through vitellogenesis process (Lubzens et al., 2010; Ding, 2005). In the natural condition, the level of Vtg indicates the stage of gonad maturation in female species (Hara et al., 2016). The Vtg was devoid in male as well as in immature females, but exist in mature vitellogenic females (Fenske et al., 2001). However, these organisms will generate the Vtg if they are carried out with synthetic estrogens, mainly 17ß-estradiol (Leonardi et al., 2010; Boucard et al., 2008). Basically, the Vtg is able to be found in matured females and is identified in a least amount which can be acknowledged insignificant in males and immature females (Muhammad et al., 2011).

Previous studies reported that 17ß-estradiol successfully induced the synthesis of vtg in many fish species (Mendoza et al., 2011). The 17ß-estradiol stimulates the liver to synthesize and secrete Vtg which is concentrated in the oocyte. The correlation between changes in gonadal steroid plasma levels and the development of oocytes has been noticed in a number of freshwater species including catfish Hemibagrus nemurus (Adebiyi et al., 2013), kutum Rutilus frisii (Sabet et al., 2009), mahseer Tor tambroides (Ismail et al., 2011), Indian shad Tenualosa ilisha (Pramanick et al., 2013), marine species including gilthead seabream Sparus aurata (Pozo et al., 2008), and pejerrey Odontesthes bonariensis (Elisio et al., 2014). Scientific information about reproductive physiology including vitellogenesis is strictly valuable in fish broodstock management.

Study on vitellogenin and $17 \beta$-estradiol level in striped catfish and scientific information about its reproduction and vitellogenesis are definitely required. In farm management, an advance understanding of vitellogenesis is very crucial to determine the maturity status of the species. Thus, this study purposed to evaluate the profile of Vtg, 17ß-estradiol levels in plasma and egg diameter on gonad maturation process of striped catfish (Pangasianodon hypophthalmus).

\section{MATERIALS AND METHODS}

\section{Experimental fish}

This study was done at the Research Institute for Fish Breeding, Ministry of Marine Affairs and Fisheries, West Java, Indonesia. The striped catfish (Pangasianodon hypophthalmus) were obtained from a broodstock population at the Institute. Males, mature, and immature females $(\mathrm{N}=30$; mature female $3302.55 \pm 276.82 \mathrm{~g}$, $53.875 \pm 1.07 \mathrm{~cm}$; male $3099.6 \pm 981.04,56.08$ 
$\pm 5.68 \mathrm{~cm}$; immature female $104.8 \pm 2.28 \mathrm{~g}$, $17.9 \pm 0.22 \mathrm{~cm}$ ) were used as the experimental fish. The mature female (gonad maturity stage I, II, III, and IV), male and immature female were measured 17ß-estradiol and Vtg concentration in blood plasma. The male and immature female were used as negative control of this parameters. Egg diameter was measured on each of the gonad maturity stage to observed gonadal development of mature females.

\section{Plasma 17 $\beta$-estradiol and vitellogenin concentrations}

Blood samples were collected formeasurements of plasma 17ß-estradiol and Vtg concentrations. Three millilitres of blood was collected from each tested fish using heparinized syringe containing phenylmethylsolfonyl fluoride, PMSF (Roche, Germany) (100 $\mu \mathrm{L}, 1 \mathrm{mM})$. The blood was stored on ice and centrifuged at $3000 \mathrm{rpm}$ for $15 \mathrm{~min}$ at $4^{\circ} \mathrm{C}$. The supernatant (plasma) was stored at $-20^{\circ} \mathrm{C}$ prior to analyze by ELISA (EIA1561 DRG International Inc., Marburg, Germany) to measure 17ß-estradiol level and sodium dodecyl sulfate polyacrylamide gel electrophoresis (SDSPAGE) method to measure Vtg.

Detection of the Vtg from the plasma of tested catfish was conducted using SDS polyacrylamide gel electrophoresis (SDS-PAGE) (Bio-Rad, Hercules, California, USA) (Walker, 2002). The quantification of the detected $\mathrm{Vtg}$ was measured using the Bradford method (Kruger, 2002).

\section{Egg diameter}

Egg diameter was measured using an binokuler microscope Olympus BX 21. For each fish, the diameter of thirty eggs were measured and the average egg diameter was calculated. The egg development was characterized based on the diameter size of the eggs on a particular stage. Photomicrographs of various stages of egg development were taken using a Olympus BX 21 microscope. For the histological observation, eggs were fixed in Bouin's solution for 24 hours and then embedded in paraffin. The paraffin embedded specimens were sectioned in 5 to 6 $\mu \mathrm{m}$ thick sections. The sections were stained with Mayer's hematoxylin-eosin, and observed under a light microscope (Olympus BX 21).

\section{Data analysis}

The data of the 17ß-estradiol and Vtg level were presented descriptively to describe the changes of $17 ß$-estradiol and Vtg level development. Data of egg diameter was statistically analyzed using Microsoft Excell 2016 and SPSS version 25.

\section{RESULTS AND DISCUSSIONS}

\section{Results}

\section{$17 \beta$-estradiol concentration}

The concentrations of 17ß-estradiol hormone on several maturity stage of female, male and immature female are presented in Figure 1. The highest concentration value of $17 ß$-estradiol was shown in the blood plasma of the female fish with maturity stage III $(843.65 \mathrm{pg} / \mathrm{mL})$ and the lowest concentration at the male fish $(26.34 \mathrm{pg} / \mathrm{mL})$. The 17ß-estradiol concentration value in blood plasma increased from stage I $(102.50 \mathrm{pg} / \mathrm{mL})$ to stage II $(326.45 \mathrm{pg} / \mathrm{mL})$ and III $(843.65 \mathrm{pg} / \mathrm{mL})$ then decreased at stage to IV $(80.45 \mathrm{mg} / \mathrm{mL})$ of ovarian development. Male and immature female fish have low concentration value of $17 \beta$-estradiol (26.35 pg/mL and $29.37 \mathrm{pg} / \mathrm{mL}$ ).

\section{Vitellogenin concentration}

Result of electrophoresis showed that protein band of Vtg was obtained on the plasma of the mature female (stage I, II, III, and IV) with a molecular weight between 140-180 kDa, but it was not obtained on immature female and male striped catfish (Figure 2). Estimation of molecular weight of Vtg protein band was calculated by comparing with molecular weight of marker.

The highest concentration value of $\mathrm{Vtg}$ was found in the blood plasma of the female fish with maturity stage III and the lowest concentration at stage IV (Figure 3). Vtg content in blood plasma increased gradually from stage I $(68.58 \mathrm{mg} / \mathrm{mL})$ to stage II $(74.83 \mathrm{mg} / \mathrm{mL})$ and III $(87.34 \mathrm{mg} /$ $\mathrm{mL})$ then decreased at stage IV $(33.45 \mathrm{mg} / \mathrm{mL})$ of ovarian development. Concentration value of vitellogenin in blood plasma were not found in male and immature female.

\section{Egg diameter}

The egg development process was proved by the size of egg diameter. Egg diameter for each maturation stage was $0.107 \pm 0.052 \mathrm{~mm}$ (stage I), $0.318 \pm 0.086 \mathrm{~mm}$ (stage II), $0.864 \pm 0.099 \mathrm{~mm}$ (stage III), and $1.041 \pm 0.058 \mathrm{~mm}$ (stage IV). A steady increase was observed in the egg diameter throughout the maturation stages. Statistical analysis showed significant differences between maturation stage $(\mathrm{P}<0.05)$. Egg diameter $(1.041$ $\pm 0.058 \mathrm{~mm}$ ) was found to be greater at stage IV of ovarian development. There was a gradual increase in egg diameter from stage I to IV which reflects egg growth leading to vitellogenesis in the final stage of ovarian development IV (Figure 4 and 5). 


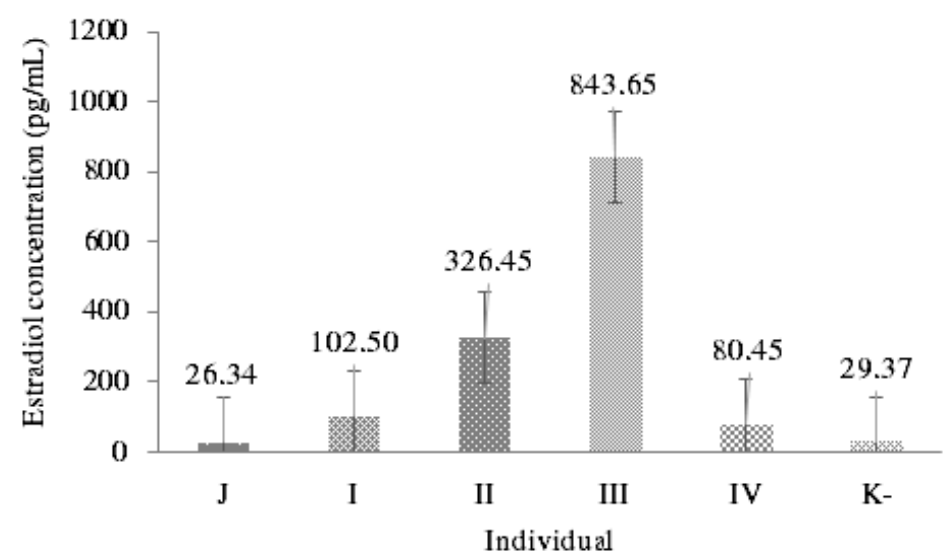

Figure 1. Estradiol concentration (pg/mL) of J (male), IV (female on maturity stage IV), III (female on maturity stage III), II (female on maturity stage II), I (female on maturity stage I), and K- (immature female as a negative control).

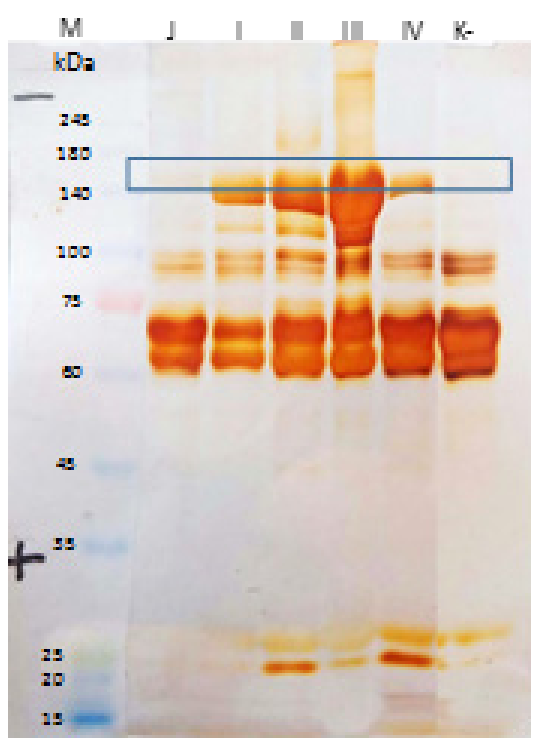

Figure 2. The profile of protein band of Vtg plasma of the female and male of various maturity stages on SDSPAGE (7.5\% SDS) stained with silver staining. Lane M : molecular weight markers (Fermentas, USA), Lane J : Male as a negative control, Lane I : maturity stage I, Lane II : Maturity stage II, Lane III : maturity stage III, Lane IV : vitellogenic female on matur stage IV, Lane K- : Immature female as a negative control.

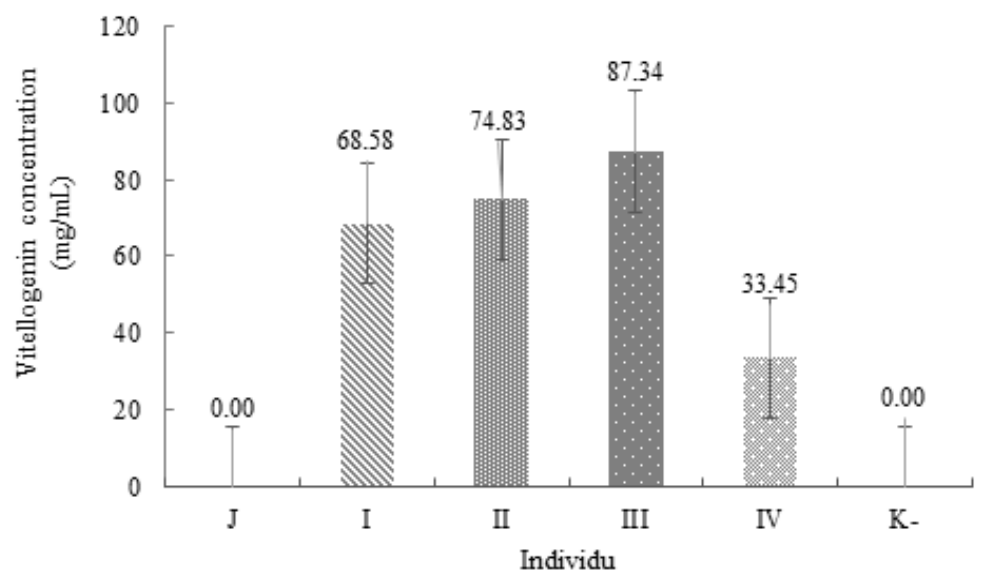

Figure 3. Vitellogenin concentration ( $\mathrm{mg} / \mathrm{mL}$ ) of J (male), IV (female on maturity stage IV), III (female on maturity stage III), II (female on maturity stage II), I (female on maturity stage I), and K- (immature female as a negative control) 


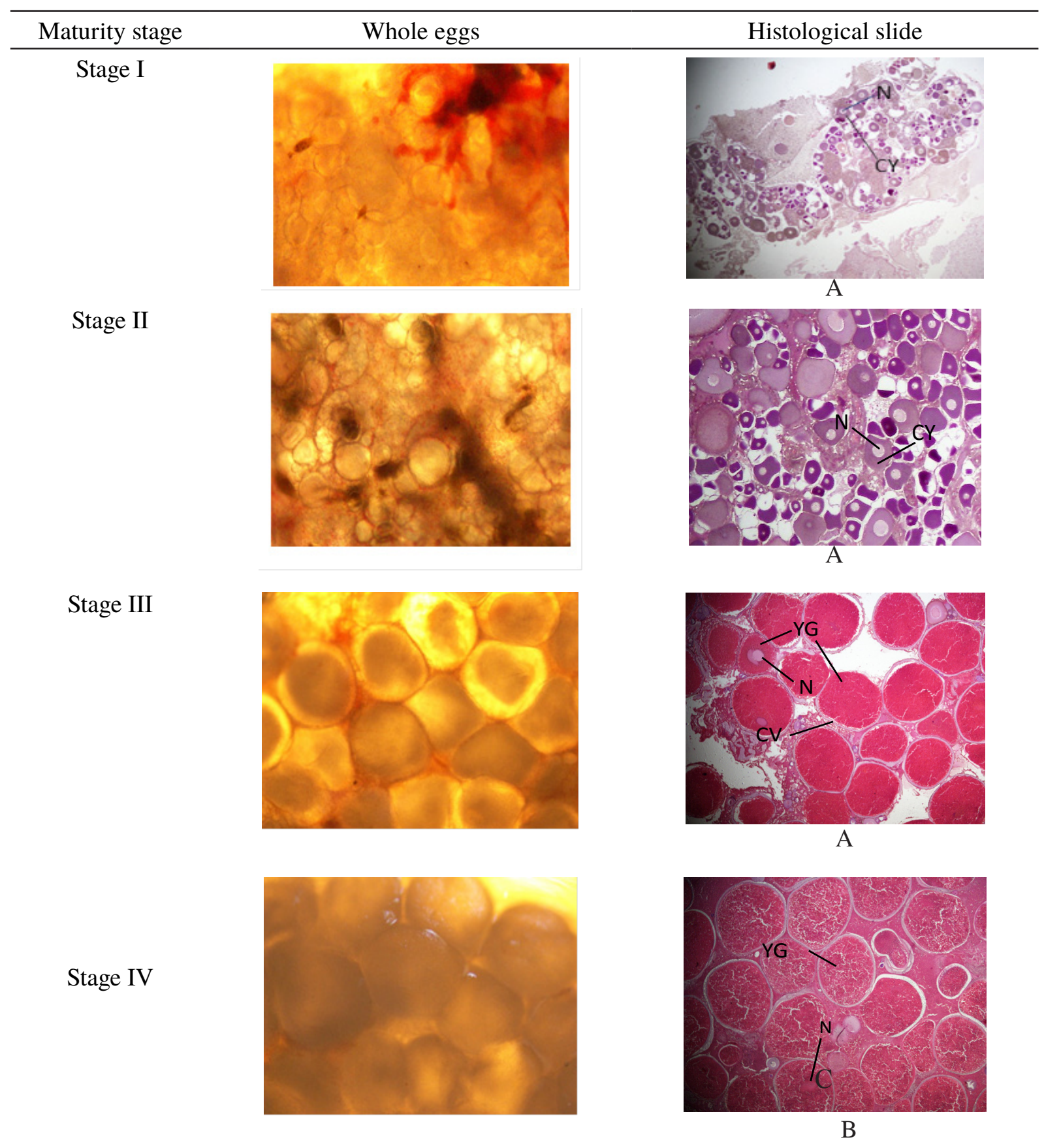

Figure 4. Egg development on four maturity stages of striped catfish Pangasianodon hypophthalmus $(\mathrm{n}=$ nucleus, $\mathrm{cy}=$ cytoplasma, $\mathrm{cv}=$ corticol vesicle, $\mathrm{yg}=$ yolk globule $\mathrm{A}=$ previtellogenesis, $\mathrm{B}=$ vitellogenesis, $\mathrm{C}=$ mature $)$. 


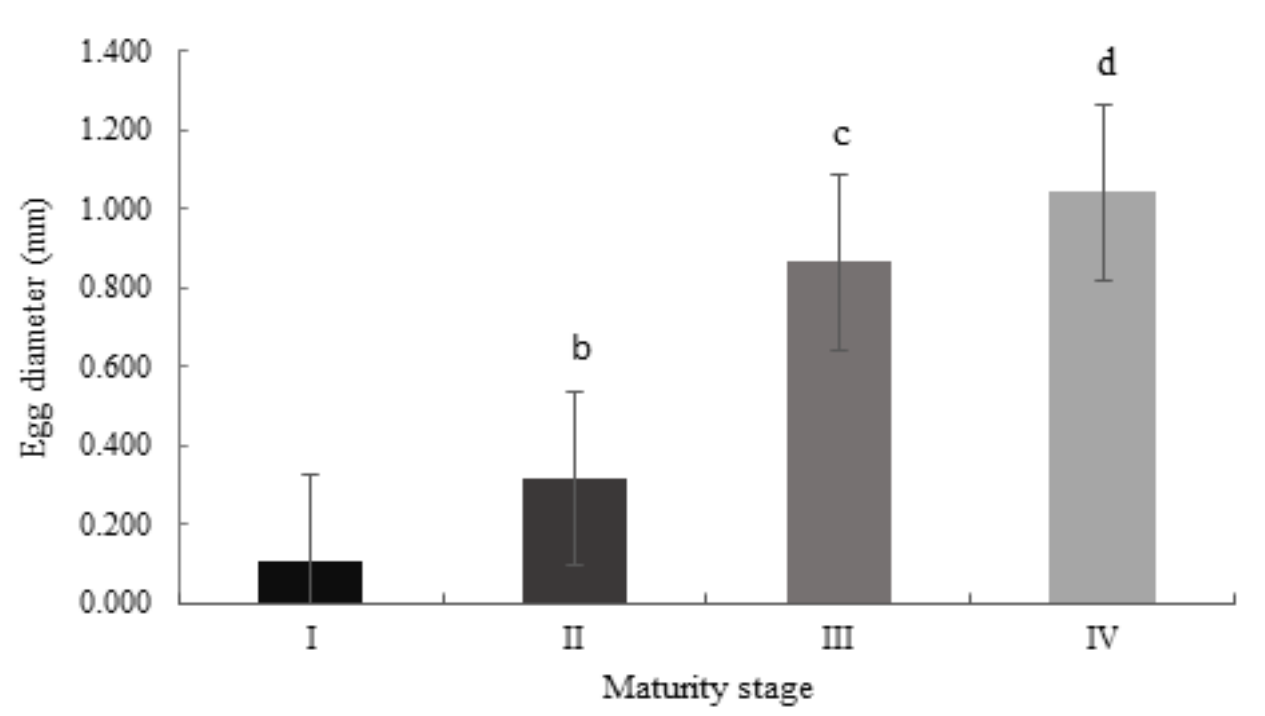

Figure 5. Egg diameters on four maturity stages of striped catfish Pangasianodon hypophthalmus

\section{Discussion}

The primary aim of the present study was to evaluate the profile of 173 -estradiol, Vtg levels in plasma, and egg diameters on gonad maturation process of striped catfish Pangasianodon hypophthalmus. In this study, we evaluated the transformation in plasma levels of 17ß-estradiol and Vtg during gonad maturation process in striped catfish. Gonad maturity development of striped catfish was observed based on egg diameter. The 17ß-estradiol and Vtg levels in the blood plasma were closely related to the stage of ovary maturity (Lubzens et al., 2010; Baumann et al., 2013; Chatakondi and Kelly, 2013). The 17ß-estradiol is the primary steroid in vitellogenesis and play a role to induce hepatic vitellogenin which synthesizes vitellogenin (Vtg), an essential precursor for the oocytes formation, ovarian growth, and steroidogenesis (Amaral et al., 2019, Samaee et al., 2009; Shappell et al., 2010; Tortolero et al., 2010; Dammann et al., 2011). In addition, the increase of steroid hormone at the maturation stage is followed by high GSI value at the mature stage of female. Ghosh et al. (2016) reported that the gradual increase of $17 \beta$-estradiol in plasma during vitellogenesis, increased Vtg level and ovarian weight consistently, reaching the peak in the pre-spawning. The 17ß-estradiol is particularly detected in mature females and not normally detected in juveniles and males, whereas injection of exogenous estrogen can induce the Vtg expression.

Result of this study showed that Vtg band was detected in blood plasma of mature female (stage I, II, III, and IV), but not detected on male and immature female of striped catfish. Currylow et al. (2013) reported that Vtg band was not detected among any male samples of Eastern box turtle Terrapene carolina as negative sample and found Vtg band in female blood plasma as positive sample. Muntaziana et al. (2011) revealed that it is difficult to measure the level of Vtg in male and immature fish, but the administration of $17 ß$-estradiol to male and juvenile teleost evidently induced accumulation of $\mathrm{Vtg}$ in the blood. The Vtg protein band of mature female was observed between 140-180 kDa of MW. In some fish species, the molecular weight of $\mathrm{Vtg}$ is between $140-200 \mathrm{kDa}$ (Komatsu \& Hayashi, 1997). Ding (2005) reported that the molecular weight of Vtg ranged between $200-700 \mathrm{kDa}$, for example killifish, Fundulus heteroclitus, which has monomeric Vtg about $200 \mathrm{kDa}$.

Gonad maturation processes correlated to $\mathrm{Vtg}$ and 17ß-estradiol levels. Plasma level of gonadal steroids can be used as gonadal activity indicator during the reproductive cycle (Nagahama \& Yamashita, 2008). Based on Figure 2 and 3, it showed increasing level of $\mathrm{Vtg}$ and $17 \beta$-estradiol in blood plasma of mature female. It was predicted that the peak of vitellogenesis process occurred on maturation stage III, thus, Vtg has been absorbed by oocytes on maturation stage IV resulted in decreased concentration of 17ß-estradiol. The 17ß-estradiol concentration in fish naturally decreased after gonad maturation. The completion of vitellogenesis is followed by a sharp decline in 17ß-estradiol levels and usually occurs with the onset of full oocyte maturation (Zupa et al., 2017). High concentrations of Vtg and 17ß-estradiol hormone were associated with gonad maturity stages. Reading et al. (2017) 
reported that 17ß-estradiol stimulates the hepatic synthesis and secretion of vitellogenin, which is assimilated into developing oocytes. Quinitio et al. (1994) reported that differences in serum Vtg levels during the stage of gonadal maturity correlated with fluctuations in $17 ß$-estradiol and progesterone levels in the hemolymes of Penaeus monodon. The ovary produces 17ß-estradiol and releases it to the blood plasma and reaches the hepatopancreas to stimulate Vtg synthesis. Revathi et al., (2012) revealed that the variations in the vitellogenin content in hepatopancreas and hemolymph differed significantly during different ovarian stages of freshwater female prawn Macrobrachium rosenbergii (De Man).

The absorption of Vtg by oocytes affects the increase of egg diameter. Egg diameter increases when the ovarian development stage progressed, resulting in an increase in ovarian volume (Figures 4 and 5). The highest average of egg diameter was at maturity stage IV. This is in accordance with Tsukimura (2001) which state that the deposition of egg yolk in the oocytes when vitellogenesis occured, resulted in an accelerated increase in oocyte diameter. The oocytes and ovaries increase in size and volume along with ovary differentiation stages (Islam et al., 2010). Therefore, it can be stated that the determination of oocyte diameter provides important information about the classification of ovary differentiation stages (Peixoto et al., 2005).

This study demonstrated that the classification of ovary differentiation stages can be based on the size of the eggs and the levels of 17ß-estradiol and Vtg during gonad maturation process. On the other hand, it evidenced that biochemical constituents are also closely associated with the ovarian development. Vitellogenesis, which is a biomarker of female reproductive activity, shows increased vitelin accumulation in oocytes and fluctuated in Vtg content in blood plasma during the fish ovary development stages.

\section{CONCLUSION}

The highest concentration value of $17 ß$-estradiol and vitellogenin was shown in the blood plasma of the female fish with maturity stage III. Vtg band was detected in blood plasma of mature female (stage I, II, III and IV) but was not detected on male and immature female of striped catfish. The changes of $17 \beta$-estradiol and vitellogenin level were followed by a gradual increase in the egg diameter throughout the maturity stages.

\section{REFERENCES}

Adebiyi FA, Siraj SS, Harmin SA, Christianus A. 2013. Plasma sex steroid hormonal profile and gonad histology during the annual reproductive cycle of river catfish Hemibagrus nemurus (Valenciennes, 1840) in captivity. Fish Physiology and Biochemistry 39: 547-557

Ahmed GU, Chakma A, Shamsuddin M, Minar MH, Islam T, Majumdar MZ. 2013. Growth performance of Thai pangus Pangasianodon hypothalamus using prepared and commercial feed. International Journal of Life Sciences, Biotechnology and Pharma Research 2: 92-102.

Amaral JS, Venturieri RL, Moreira RG. 2019. Gonadal steroids and energy availability during ovarian maturation stages of the Amazonian pirarucu Arapaima gigas (teleostei: Osteoglossidae) in the wild. Comparative Biochemistry and Physiology part A: Molecular and Integrative Physiology 230: 106-114.

Asdari R, Hashim R, Aliyu-Paiko M, Ramachandran S. 2010. Effect of different dietary lipid sources in the diet for Pangasius hypophthalmus (Sauvage, 1878) juvenile on growth performance, nutrient utilization, body indices and muscle and liver fatty acid composition. Aquaculture Nutrition 17: 44-53.

Baumann L, Holbech H, Keiter S, Kinnberg KL, Knorr S, Nagel T, Braunbeck T. 2013. The maturity index as a tool to facilitate the interpretation of changes in vitellogenin production and sex ratio in the fish sexual development test. Aquatic Toxicology 128-129: 34-42.

Boucard CV, Aceves MB, Ortega FA, Vega GA. 2008. Validation of an enzymelinked immunosorbent assay for measuring vitellogenin in California halibut Paralichthys californicus. Environmental Toxicology and Chemistry 27: 1614-1620.

Bui TM, Phan LT, Ingram BA, Nguyen TTT, Gooley GJ, Nguyen HV, Nguyen PT, De Silva 
SS. 2010. Seed production practices of striped catfish, Pangasianodon hypophthalmus in the Mekong Delta region, Vietnam. Aquaculture 306: 92-100.

Chatakondi NG, Kelly AM. 2013. Oocyte diameter and plasma vitellogenin as predictive factors to identify potential channel catfish, Ictalurus punctatus, suitable for induced spawning. World Aquaculture Society 44: 115-123.

Currylow AF, Tift MS, Meyer JL, Crocker DE, William RN. 2013. Seasonal variations in plasma vitellogenin and sex steroids in male and female Eastern box turtles, Terrapene carolina Carolina. General and Comparative Endocrinology 180: 48-55.

Dammann A, Shappell N, Bartell S, Schoenfussa H. 2011. Comparing biological effects and potencies of estrone and $17 \beta$-estradiol in mature fathead minnows Pimephales promelas. Aquatic Toxicology 105: 559-568.

Ding JL. 2005. Vitellogenesis and vitellogenin uptake into oocyte. In: Melamed P, Sherwood $\mathrm{N}$ (eds) Hormones and their receptors in fish reproduction. World Scientific Publishing, Singapore pp. 254-276

Dominguez GA, Quattro JM, Denslow ND, Kroll KJ, Prucha MS, Porak WF, Grier HJ, Sabo-Attwood TL. 2012. Identification and transcriptional modulation of the largemouth bass, Micropterus salmoides, vitellogenin receptor during oocyte development by insulin and sex steroids. Biology of Reproduction 87: $1-12$.

Elisio M, Chalde T, Miranda LA. 2014. Seasonal changes and endocrine regulation of pejerrey Odontesthes bonariensis oogenesis in the wild. Comparative Biochemistry and Physiology Part A: Molecular and Integrative Physiology 175: 102-109.

Fenske M, Aerle RV, Brack S, Tyler CR, Segner H. 2001. Development and validation of a homologous zebrafish Danio rerio (Hamilton-Buchanan) vitellogenin enzymelinked immunosorbent assay (ELISA) and its application for studies of estrogenic chemicals. Comparative Biochemistry and Physiology 129: 217-232.

Ghosh P, Das D, Juina SK, Hajraa K, Kachari A, Das DN, Natha P, Maitraa S. 2016. Identification and partial characterization of Olyra longicaudata (McClelland, 1842) vitellogenins: Seasonal variation in plasma, relative to estradiol-17 $\beta$ and ovarian growth. Aquaculture Reports 3: 120-130.

Hara A, Hiramatsu N, Fujita T. 2016. Vitellogenesis and choriogenesis in fish. Fisheries Science 82: 187-202

Islam MS, Kodama K, Kurokura H. 2010. Ovarian development of the mud crab Scylla paramamosain in a tropical mangrove swamps, Thailand. Journal of Scientific Research 2: 380-389.

Ismail MFS, Siraj SS, Daud SK, Harmin SA. 2011. Association of annual hormonal profile with gonad maturity of mahseer Tor tambroides in captivity. General and Comparative Endocrinology 170: 125-130.

Komatsu M, Hayashi S. 1997. Parmacological dose of estradiol-17 $\beta$ Induces vitellogenin synthesis in cultured hepatocytes of immature eel Anguilla japonica. Fisheries Science 63: 989-994.

Kruger NJ. 2002. The Bradford method for protein quantification. In J. M. Walker (Ed.), The Protein Protocols Handbook (pp. 15-21). Totowa, New Jersey: Humana Press.

Kumar KK, Prasad P, Raman RP, Kumar S, Purushothaman CS. 2013. Association of Enterobacter cloacae in the mortality of Pangasianodon hypophthalmus (Sauvage, 1878) reared in culture pond in Bhimavaram, Andhra Pradesh, India. Indian Journal of Fish 60:147-149.

Leonardi M, Vera J, Terifeno E, Puchi M, Marin V. 2010. Vtg of the Chilean flounder Paralichthys adpersus as a biomarker of the South Pacific. Part 1: induction, isolation and identification. Fish Physiology and Biochemistry 36: 757765.

Liu W, Li Q, Kong L. 2008. Estradiol-17ß and testosterone levels in the cockle Fulvia mutica during the annual reproductive cycle. New Zealand Journal of Marine and Freshwater Research 42: 417-424.

Lubzens E, Young G, Bobe J, Cerda J. 2010. Oogenesis in teleosts: how fish eggs are formed. General and Comparative Endocrinology 165: 367-389.

Luck C, Mejri S, Lewis J, Wills PS, Riche M, Shenker J, Adams A, Ajemian MJ. 2019. Seasonal and spatial changes in sex hormone 
levels and oocyte development of bonefish Albula vulpes. Environmental Biology of Fish 102: 209-219

McGee MV. 2014. Pangasius hypothalamus, a potential aquaculture species for tropical regions of the Americas. (unpublished)

Mendoza B, Gómez-Marquez J,García- Alberto G. 2011. Ciclo reproductor e histología de las gónadas de Oreochromis niloticus. Ciencia Pesquera 19: 23-36.

Ministry of Fisheries and Marine Affairs Republic of Indonesia. 2018. Fish Market News. Directorate of Logistics Systems. http://www. wpi.kkp.go.id

Moses TLS, Felix S, Thiruvengadam V. 2016. Induced breeding, egg and embryonic developmentof Pangasianodon hypophthalmus (Sauvage, 1878) under hatchery conditions of north Tamil Nadu (Chennai). International Journal of Fisheries and Aquatic Studies 4: 388-392.

Muhammad NA, Christianus, Daud SK, Saad CR, Harmin SA, Salwany MYI. 2011. EstrogenInduced Vitellogenin in Tor tambroides (Bleeker, 1854): Purification, Characterization and ELISA Development. Journal Aof Fisheries and Aquatic Science 6: 700-714.

Muntaziana MPA, Rahim AA, Harmin SA, Amin SMN. 2011. Estrogen-induced vitellogenin in Tor tambroides (Bleeker, 1854): Purification, characterization and ELISA development. Journal of Fisheries Aquatic Science 6: 700-714.

Nagahama Y, Yamashita M. 2008. Regulation of oocyte maturation in fish. Development Growth and Differentiation 50: S195-S219.

Ni J, Zeng Z, Ke C. 2013. Sex steroid levels and expression patterns of estrogen receptor gene in the oyster Crassostrea angulata during reproductive cycle. Aquaculture 376-379, 105-116.

Phan LTT, Bui M, Nguyen TTT, Gooley GJ, Ingram B A, Nguyen H V. 2009. Current status of farming practices of striped catfish, Pangasianodon hypophthalmus in the Mekong Delta, Vietnam. Aquaculture 296: 227-236.

Pramanick K, Kundu S, Paul S, Mallick B, Moulik SR, Pal P, Mukherjee D. 2013. Changes in plasma steroid levels during oocyte development in Indian shad, Tenualosa ilisha (Hamilton, 1822): Role of gonadotropins on in vitro steroid production and development of oocyte maturational competence. Animal Reproduction Science 141: 177-188.

Peixoto S, Cavalli RO, Wasielesky W. 2005. Recent developments on broodstock maturation and reproduction of Farfantepenaeus paulensis. Brazilian Archives of Biology and Technology 48: 997-1006.

Pozo EC, Arjona FJ, López AG, Alcázar AG, Meseguer J, Ayala AG. 2008. Sex steroids and metabolic parameter levels in a seasonal breeding fish Sparus aurata L. General and Comparative Endocrinology 156: 531-536.

Quinitio ET, Hara A, Yamauchi K, Nakao S. 1994 Changes in the steroid hormone and vitellogenin levels during the gametogenic cycle of the giant tiger shrimp, Penaeus monodon. Comparative Biochemistry and Physiology 109: 21-26.

Reading BJ, Sullivan CV, Schilling J. 2017. Vitellogenesis in Fish. Reference Module in Life Sciences. 1-14.

Revathi P, Iyapparaj P, Munuswamy N, Krishnan M. 2012. Vitellogenesis during the ovarian development in freshwater female prawn Macrobrachium rosenbergii (De Man). International Journal of Aquatic Science 3: 13-27.

Sabet SS, Imanpoor, Mohammad, Reza, Fatideh A, Bagher, Gorgin, Saeed. 2009. Study on sexual maturity and levels of gonad steroid hormones in female kutum Rutilus frisii kutum (Kamenskii, 1901) during spawning season from river Sefid-Rood of the southern Caspian sea. Journal of Cell and Animal Biology 3: 208-215.

Samaee S, Lahnsteiner F, Gimenez G, Estevez A, Sarg B, Linder H. 2009. Quantitative composition of

vitellogenin-derived yolk proteins and their effects on the viability of embryos and larvae of common dentex Dentex dentex, a marine Pelagophil teleost. Journal of Experimental Zoology Part A 311: 504-520.

Shappell N, Hyndman K, Bartell S, Schoenfuss H. 2010. Comparative biological effects and potency of 17 alfa- and 17 beta-estradiol in fathead minnows Pimephales promelas. Aquatic Toxicology 100: 1-8.

Singh AK, Lakra WS. 2012. Culture of Pangasianodon hypothalamus into India: impacts and present scenario. Pakistan Journal of Biology Science 15: 19-26. 
Tortolero D, Campos-Ramos R, Burgos-Aceves M, Urbiola J, Duran G. 2010. Effects of compressed seasonally changing day-length cycles on spawning performance, production of viable eggs and levels of vitellogenin in plasma in female yellowtail snapper Lutjanus argentiventris. Journal of Fish Biology 77: 2285-2297.

Tsukimura B. 2001. Crustacean vitellogenesis: its role in oocyte development. American. Zoologist 41: 465-476.

Tirado JO, Valladares L, Muñoz D, Caza J, Manjunatha B, Kundapur RR. 2017. Levels of 17ß-estradiol, Vtg, and prostaglandins during the reproductive cycle of Oreochromis niloticus. Latin American Journal of Aquatic Research 45: 930-936
Walker JM. 2002. SDS polyacrylamide gel electrophoresis of proteins. In J. M. Walker (Ed.), The Protein Protocols Handbook pp. 61-67. Totowa, New Jersey: Humana Press.

Yan H, Li Q, Liu W, Ke Q, Yu R, Kong L. 2011. Seasonal changes of estradiol-17 $\beta$ and testosterone concentrations in the gonad of the razor clam Sinonovacula constricta (Lamarck, 1818). Journal Molluscan Studies 77: 116-122.

Zupa R, Rodroaguez C, Mylonas CC, Rosenfeld H, Fakriadis I, Papadaki M, Pérez J, Pousis C, Basilone G, Corriero A. 2017. Comparative study of reproductive development in wild and captive-reared greater amberjack Seriola dumerili (Risso, 1810). PLoS One 12: 1-28. 